УДК 619.616.993.192

DOI: 10.31016/1998-8435-2021-15-2-95-100

Original article

\title{
The influence of coccidiostatic Baycox on the course of coccidiosis in broiler chicken
}

\author{
Aleksandra Balicka-Ramisz ${ }^{1}$, Łukasz Laurans ${ }^{2}$, Mirosława Batko ${ }^{3}$, Anna Ramisz ${ }^{4}$ \\ ${ }^{1}$ Department of Biotechnology of Animal Reproduction and Environment Hygiene, \\ West Pomerania University of Technology; Szczecin, Poland, e-mail: abalicka52@gmail.com \\ ${ }^{2}$ Clinic of Infectious Diseases, Hepatology and Liver Transplantation, Pomeranian Medical University, \\ 4, Arkońska st., 71-455 Szczecin, Poland \\ ${ }^{3}$ Master of Biology High School Elbląg, Poland \\ ${ }^{4}$ Student, Pomeranian Medical University, Szczecin, Poland
}

Received on: 05.11.2020; accepted for printing on: 12.01.2021

\begin{abstract}
The purpose of the research is to identify species of Eimeria spp. in chicken broilers suspected to be infected with coccidia and to determine the effect of coccidiostatics in the course of coccidiosis.

Materials and methods. The study involved 20 six-week-old broiler chickens obtained from a farm heavily affected by coccidia (natural infection - a high oocyst incidence). Each group yielded 10 randomly picked chickens to be used in the experiment. The birds were divided into 2 groups 10 chickens each: control (I); Baycox-treated (II); Baycox was applied for 2 days in a concentration of 25 ppm in drinking water. Samples of broiler chickens' droppings were tested qualitatively by the flotation method (Willis-Schlaaf) and then quantitatively by the McMaster technique. The chickens were killed 6 days post-treatment and their intestinal mean total lesion scores (MTLS) were graded 0 to 4 on an arbitrary scale described by Johnson and Reid (1970).

Results and discussion. As a result of the research, six species of protozoa of the genus Eimeria were identified: E. acervulina, E. tenella, E. brunetti, E. maxima, E. mivati, E. necatrix, while E. necatrix and E. maxima were the dominant species. This proves the presence of such species as E. mivati, E. acervulina (76.34\%) in the anterior segment of the intestine and E. necatrix, E. maxima (83.34\%) - in the middle segment of the small intestine. Infections of E. brunetti broilers amounted to $51.11 \%$. The most pathogenic species of E. tenella residing in the cecum was found in $37.53 \%$. MTLS in the group of chickens that received Baycox was 0.33 . The post-treatment oocyst indices in the second group amounted to 1 (1-50 oocysts in $1 \mathrm{~g}$ of faeces), in the control group MTLS was very high $(2,5)$, the oocyst index exceeding 3.
\end{abstract}

Keywords: coccidiosis, chickens, control, prophylaxis, prevalence

Financial Disclosure: none of the authors has financial interest in the submitted materials or methods.

There is no conflict of interests

For citation: Balicka-Ramisz A., LauransŁ., Batko M., Ramisz A. The influence of coccidiostatic Baycox on the course of coccidiosis in broiler chicken. Rossiyskiy parazitologicheskiy zhurnal = Russian Journal of Parasitology. 2021; 15 (2): 95-100.

https://doi.org/10.31016/1998-8435-2021-15-2-95-100

(c) Balicka-Ramisz A., Laurans Ł., Batko M., Ramisz A., 2021

Контент доступен под лицензией Creative Commons Attribution 4.0 License.

The content is available under Creative Commons Attribution 4.0 License. 
Оригинальная статья

\title{
Влияние кокцидиостатика байкокса на течение кокцидиоза у цыплят-бройлеров
}

\author{
Александра Балицка-Рамиш ${ }^{1}$, Лукаш Лауранс ${ }^{2}$, Мирослава Батко ${ }^{3}$, Анна Рамиш ${ }^{4}$ \\ ${ }^{1}$ Кафедра биотехнологии репродукции животных и гигиены окружающей среды, \\ Западно-Поморский технический университет, г. Щецин, Польша, e-mail: abalicka52@gmail.com \\ ${ }^{2}$ Клиника инфекционных заболеваний, гепатологии и трансплантации печени, Поморский медицинский \\ университет, ул. Арконска, 4, 71-455, г. Щецин, Польша 3 Средняя школа, г. Эльблонг, Польша \\ ${ }^{4}$ Поморский медицинский университет, г. Щецин, Польша
}

Поступила в редакцию: 05.11.2020; принята в печать: 12.01.2021

\begin{abstract}
Аннотация
Цель исследований: идентификация обнаруженных у цыплят-бройлеров кокцидий Eimeria spp. и оценка эффективности байкокса против кокцидий.

Материалы и методы. Исследовано 20 цыплят-бройлеров в возрасте 6 недель с фермы, неблагополучной по кокцидиозу. Цыплят разделили на две равные группы. Первая группа цыплят была контрольной и им препарат не задавали. Цыплятам второй группы задавали байкокс в течение 2 сут в концентрации 25 ч/млн вместе с водой. Пробы помета цыплят-бройлеров исследовали качественно методом флотации (Willis-Schlaaf), а затем количественно методом МакМастера. Цыплят умерщвляли через 6 сут после обработки, и их средние показатели общего поражения кишечника оценивали от 0 до 4 баллов по произвольной шкале, описанной Johnson and Reid (1970).

Результаты и обсуждение. По результатам исследований выявлено шесть видов простейших рода Eimeria: $E$. acervulina, E. tenella, E. brunetti, E. maxima, E. mivati, E. necatrix, при этом виды E. necatrix и E. тахіта были доминирующими. Виды E. mivati, E. acervulina (76,34\%) локализовались в переднем сегменте кишечника, E. necatrix, E. maxima (83,34\%) - в среднем сегменте тонкой кишки. E. brunetti обнаружены у 51,11\% исследованных цыплят. Наиболее патогенный вид, E. tenella, паразитирующий в слепой кишке, обнаружен у 37,53\% особей. Средний показатель общего поражения кишечника в группе цыплят, получавшей байкокс, составил 0,33. Уровень загрязненности фекалий ооцистами после обработки во второй группе составил 1 (от 1 до 50 ооцист в 1 г фекалий), в контрольной группе - превышал 3, а средний показатель общего поражения кишечника - 2,5.
\end{abstract}

Ключевые слова: кокцидиоз, куры, борьба, профилактика, распространение

Прозрачность финансовой деятельности: никто из авторов не имеет финансовой заинтересованности в представленных материалах или методах.

\section{Конфликт интересов отсутствует}

Для цитирования: Балицка-Рамиш А., Лауранс Э., Батко М., Рамиш А. Влияние кокцидиостатика байкокса на течение кокцидиоза у цыплят-бройлеров // Российский паразитологический журнал. 2021. Т. 15. № 2. С. 95-100. (In Eng.).

https://doi.org/10.31016/1998-8435-2021-15-2-95-100

(с) Балицка-Рамиш А., Лауранс Э., Батко М., Рамиш А., 2021

\section{Introduction}

As an environmental disease, coccidiosis continues to be a significant health problem in poultry production. According to prof. Jeffers, it is the most common disease in poultry [9]. The course of the infection of this dangerous disease is the result of many environmental factors. The outbreak of the disease may contribute to frustrating the breeder's effort by direct losses (chicken sickness and falls) as well as indirect losses manifested by worse production effects.

Seven coccidial species have been described in chickens, of which five - Eimeria tenella, E. necatrix, E. brunetii, E. acervulina and E. maxima - are considered pathogenic species. The pathogenicity of $E$. mitis and E. praecox is ambiguous - by many researchers they are classified as non-pathogenic $[5,14]$, however, more and more data indicate the 
impact of these species on the profitability of production, as infection, despite the absence of disease symptoms and falls, leads to a deterioration of the economic results of breeding $[5,11]$.

The problem of coccidiosis prevention in Poland is generally not covered by any coordination. Dispersion of feed and premix producers, the declining profitability of this industry and extremely fierce competition do not encourage activities on the coordination of activities in the field of rationalization of coccidiosis chemoprophylaxis programs. The current policy, or rather the lack of a policy regarding the use of coccidiostats in poultry production, leads to losses caused by these parasites, and they result directly from lower economic effects [3].

The aim of the present research was to identify species of Eimeria spp. in chicken broilers suspected to be infected with coccidia and to determine the effect of coccidiostats in the course of coccidiosis.

\section{Materials and methods}

Animals. The study involved 20 six-week-old broiler chickens obtained from a farm heavily affected by coccidia (natural infection - a high oocyst incidence). The chickens were kept in an electrically heated poultry house and fed ad libitum with appropriate feed and water. The basic diet contained $18 \%$ total protein, $8 \%$ fat, $4 \%$ crude fibre, $0.4 \%$ methionine, $0.3 \%$ cysteine, $18 \%$ tryptofan, $0.9 \%$ lysine, $1 \%$ calcium, and $0.5 \%$ phosphorus. Each group yielded 10 randomly picked chickens to be used in the experiment. The birds were divided into 2 groups 10 chickens each: control (I); Baycox-treated (II); Baycox was applied for 2 days in a concentration of $25 \mathrm{ppm}$ in drinking water.

Parasitologcal analysis. More specifically, fecal samples were qualitatively analyzed by using the Willis-Schlaaf flotation with saturated $\mathrm{NaCl}$ solution and a McMaster method with a detection level of Eimeria spp. oocysts per gram of feces was performed with saturated $\mathrm{NaCl}$ solution [4]. The procedures of propagation and harvesting of oocysts, and preparation of oocysts followed by recommendations Eckert [4]. The chickens were killed 6 days post-treatment and their intestinal mean total lesion scores (MTLS) were graded 0 to 4 on an arbitrary scale described by Johnson and Reid (1970) (Fig.1) [10].

\section{Results and discussion}

As a result of the research, six species of protozoa of the genus Eimeria were identified: E. acervulina, E. tenella, E. brunetti, E. maxima, E. mivati, E. necatrix, while E. necatrix and E. maxima were the dominant species (table 1).

Table 1

The infection rate of coccidia species in broiler chickens

\begin{tabular}{|l|c|c|}
\hline \multicolumn{1}{|c|}{ Coccidia species } & $\begin{array}{c}\text { Partition of intestine according } \\
\text { to Johnson-Reid }\end{array}$ & Infection rate, \% \\
\hline E. mivati, E. acervulina & 1 & 76,34 \\
\hline E. necatrix, E. maxima & 2 & 83,34 \\
\hline E. brunetti & 3 & 51,11 \\
\hline E. tenella & 4 & 37,53 \\
\hline
\end{tabular}

In the digestive tract of chicken broilers, anatomical changes were particularly frequent in the anterior and middle sections of the small intestine. This proves the presence of such species as $E$. mivati, E. acervulina (76.34\%) located in the anterior segment of the intestine and E. necatrix, E. maxima (83.34\%) located in the middle segment of the small intestine. Infections of E. brunetti broilers amounted to $51.11 \%$.

This specie is localized in the rectum and the steak. The most pathogenic species of E. tenella residing in the cecum was found in $37.53 \%$ (Table 1 ).
The analysis of the obtained results showed that in most cases broilers were affected by mixed infections with the predominance of five and six species. They were confirmed in $66.4 \%$ of the tested chickens.

In half of the farms studied, dangerously high degree of infection with chickens coccidia was demonstrated.

Baycox is a well-known coccidiostatic particularly useful for controlling poultry coccidiosis. MTLS in the Baycox-treated group was 0.33. The post-treatment oocyst indices in these groups 
amounted to 1 (1-50 oocysts in $1 \mathrm{~g}$ of faeces). The control group MTLS was very high $(2,5)$, the oocyst index exceeding 3 (more than 300 oocysts in $1 \mathrm{~g}$ of faeces) (Table 2, 3). lands, Iran, Korea, Norway, Romania and Turkey show that the most common species of coccidia, similarly to our country, were E. acervulina and E. tenella $[6,8,12,13,15]$. The research was conducted in Russia. The work was carried out in a laboratory for infection diseases of farm animals and poultry of the Caspian Zonal Scientific Research Veterinary Institute, and in the Republic poultry farms. The results of broiler chickens' cecum examinations revealed a high rate of Eimeria infection. Thus, 20-30 oocysts were found in 55 samples in a single microscope field representing $63.2 \%$. The oocysts referred to four species: $E$. tenella, E. maxima and E. mitis in the cecum and small bowel, and E. accervulina in the duodenum. 100\% efficacy of Eimeterm $2.5 \%$ and Enrofloxacin when combined with water was confirmed. The mortality rate reduced from 137 to 11 animals per day. The survivability of broiler chickens in the test group in the growing period was $94.3 \%$ [1].

Coccidiosis is a serious problem in broiler chicken production in Poland. Coccidiostatics are used to combat this disease. In last time additionally for coccidiosis control compounds are applied, which stimulated the non-specific resistance system.
Coccidiosis remains one of the major threats for poultry industry throughout the world [7]. The disease is traditionally controlled by the use of chemoprophylactic measures including anticoccidials in feed that inhibit the developmental stages of Eimeria.

The dominance of individual species of coccidia is variable and depends not only on the area, but may also change over time in the same area. From scientific reports from various countries, incl. The Czech Republic, France, the Nether-
In Poland the most frequently diagnosed species were E. tenella (64\%), E. acervulina (32\%), E. maxima (8\%), and E. necatrix (4\%). Most cases were caused by a single species of coccidia (92\%), and in $8 \%$ of cases two species of coccidia were found [5]. On the other hand, studies by Doner and Szeleszczuk showed that in the country broiler chickens were infected with several species ( $E$. acervulina, E. mitis and E. maxima), and infections with E. tenella constituted 29\% [2, 3]. 
Summary of the intestinal lesion scores of the experimental groups

\begin{tabular}{|l|c|c|c|c|c|c|}
\hline \multirow{2}{*}{ Group } & \multicolumn{4}{|c|}{ MTLS in chicken intestine ${ }^{*}$} & \multirow{2}{*}{$\begin{array}{c}\text { Average } \\
\text { MTLS from 10 chickens }\end{array}$} & \multirow{2}{*}{ Oocyst index } \\
\cline { 2 - 5 } & 1 & 2 & 3 & 4 & 2.3 & 3 \\
\hline Control & 2.6 & 2.6 & 2.2 & 1.9 & 0.31 & 0.2 \\
\hline Baycox & 0.6 & 0.4 & 0.2 & 0.1 & 0.31 & 3 \\
\hline
\end{tabular}

* - Each entry in the table is an average of data for 10 chickens

\section{Conclusion}

Despite the introduction of new diagnostic techniques into coccidiosis research, the disease remains a problem in the poultry industry. In Poland, there is no nationwide program of prevention, based on the use of coccidiostatics and vaccines against coccidiosis.
Explanation: 1, 2, 3, 4, intestinal sections identical to those in Fig. 1.

Mean Total Lesion Score (MTLS) range: 0-4 Oocyst index: 0

$$
1=1-50 \text { oocysts in } 1 \mathrm{~g} \text { faeces }
$$

$2=51-300$ oocysts in $1 \mathrm{~g}$ faeces

$3=>300$ oocysts in $1 \mathrm{~g}$ faeces

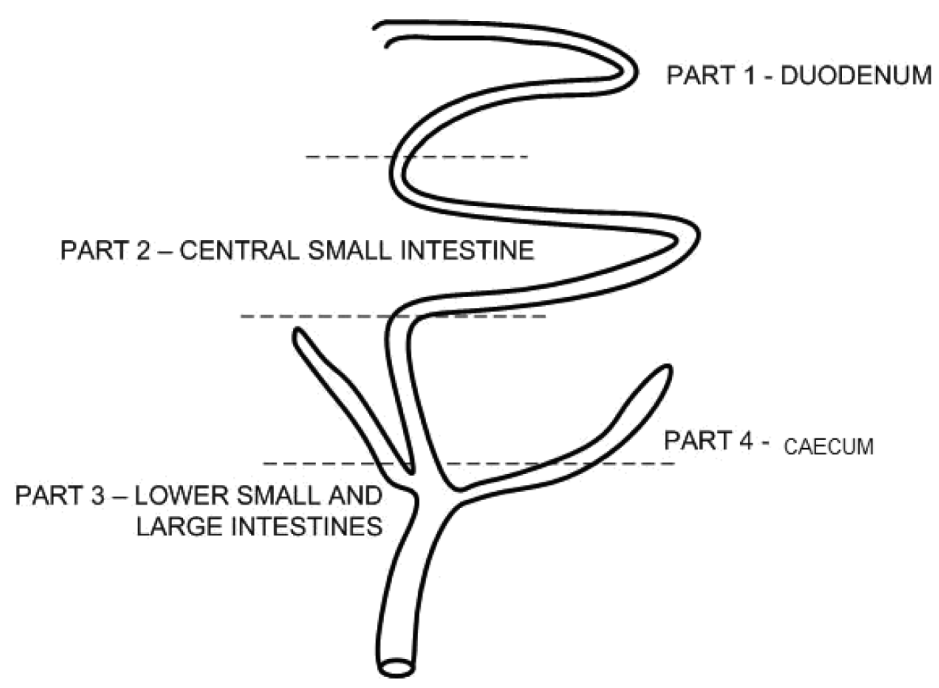

Fig. 1. Sections of broiler chicken intestine evaluated for MTLS [10]

\section{References}

1. Dagayeva A. B., Bakrieva R. M., Makhieva B. M. Eimeriosis in poultry: biology, spread and control measures in the Caspian Sea Region of the Russian Federation. Russian Journal of Parasitology. 2020; 14 (1): 29-34.

2. Doner S. Epidemiology of infection with Eimeria protozoa in vaccinated and unvaccinated broiler flocks against coccidiosis. Doctoral dissertation at SGGW Warsaw, 2018.

3. Doner S., Szeleszczuk P. Prevalence of Eimeria spp. In broiler chicken flocks in Poland. XI International Coccidiosis Conference 2014; September 2014, Dresden, Germany, s. 26-30.
4. Eckert J., Taylor M., Licois D., Coudret P., Catchpole J., Bucklar H. Identification of Eimeria and Isospora species and strains: Morphological and biological characteristics. In: Eckert J., Braun R., Shirley M. W. et al. Biotechnology. Guidelines on techniques in coccidioisis research office for official publications of the European Communities, 1995; Luxembourg.

5. Gaweł A., Bobusia K., Bobrek K. Identification of Eimeria spp. occurring in hens and broiler chickens in Poland, Med. Weter. 2015; 71 (6), 382-388.

6. Graat E., van der Kooij E., Frankena K., Henken A., Smeets J., Hekerman M.: Quantifying risk factors of coccidiosis in broilers using on-farm data based on a veterinary practice. Prev. Vet. Med. 1998; 33, 297-308. 
7. Hafez H. M. Enteric diseases of poultry with special attention to Clostridium perfringens. Pak Vet J., 2011; 31: 175-184.

8. Haug A., Gjevre A., Thebo P., Mattsson J., Kaldhusdal M. Coccidial infections in commercial broilers: epidemiological aspects and comparison of Eimeria species identification by morphometric and polymerase chain reaction techniques. Avian Pathol. 2008; 37, 161-170.

9. Jeffers Tomas. Serendiptty: my ally in coccidiosis research „Coccidiosis and other invasive poultry diseases current challenges" Intertnational Technical Conference, 23.030.2018, Wrocław.

10. Johnson J., Reid W. M. Anticoccidial drugs: Lesion scoring techniques in batter and floor-pen experiments with chicken. Exp. Parasitol. 1970; $28,30-36$.

11. Jorgensen W., Stewart N., Jeston P., Molloy J., Blight G., Dalgliesh R.: Isolation and pathogenicity of Australian strains of Eimeria praecox and Eimeria mitis. Australian Vet. J. 1997, 75, 592-595.

12. Kucera J.: Identification of Eimeria species in Czechoslovakia. Avian Pathol. 1990; 19, 59-66.

13. Lee B., Kim W., Jeong J., Yoo J., Kwon Y., Jung B., Kwon J., Lillehoj H., Min W. Prevalence and cross-immunity of Eimeria species on Korean chicken farms. J. Vet. Med. Sci. 2010; 72, 985-989.

14. Mazurkiewicz M. Choroby drobiu. Wydawnictwo Akademii Rolniczej Wrocław 2011; 599-611.

15. Williams R., Bushell A., Reperant J., Doy T., Morgan J., Shirley M., Yvore P., Carr M., Fremont Y.: A survey of Eimeria species in commerciallyreared chickens in France during 1994. Avian Pathol. 1996; 25, 113-130. 